\title{
前立腺癌に対する局所温熱療法の検討
}

\author{
浜松医科大学泌尿器科学教室（主任：河邊香月教授） \\ 平井正孝
}

\section{BASIC AND CLINICAL STUDIES OF LOCAL HYPERTHERMIA FOR PROSTATIC CANCER}

\author{
Masataka Hirai \\ Department of Urology, Hamamatsu University School of Medicine \\ (Chairman: Prof. Kazuki Kawabe)
}

The effect of local hyperthermia on the prostate using $13.56 \mathrm{MHz}$ radio frequency wave ( $\mathrm{RF}$ wave) was reported.

Firstly, temperature and blood flow of the prostate in normal dogs were measured during local hyperthermia. In most part of the prostate, the temperature reached over $42^{\circ} \mathrm{C}$, which was considered as favorable for the hyperthermia therapy. Blood flow of the prostatic tissue rose more slowly than that of muscle tissue. Secondly, the tissue concentration of anticancer agents after local hyperthermia was measured. There was a tendency that drug concentration in the prostate tissue after local hyperthermia was higher than that without local hyperthermia. Histological findings showed interstitial edema and congestion.

As a clinical trial, 14 cases of prostatic cancer were treated with local hyperthermia after the administration of anticancer agents. Seven of them were fresh cases and the others were relapsed cases. After treatment, tumor size was reduced in 13 cases. According to "The Response Criteria for Urologic Tumor", one Complete Response, 3 Partial Response and 10 No Change cases were obtained. There was no tumor progression. As for side effects, bone marrow suppression, loss of appetite, diarrhea and skin burns were noted. However, these side effects were mild, and did not interrupt the treatment.

Local hyperthermia of the prostate after systemic chemotherapy could be carried out safely and effectively in patients with prostatic cancer.

Key words: hyperthermia, prostatic cancer

要旨：13.56MHz の radio frequency wave ( $\mathrm{RF}$ 波)を用いた局所温熱療法の可能性を検討した。 ず， 正常イヌ前立腺の局所温熱療法を施し温度分布，組織血流を測定した。した。その結果，前立腺のほぼ 全域で温熱療法の至適温度とされる $42^{\circ} \mathrm{C}$ 以上に加温することが可能であった。水素ガスクリアランス法 で測定した前立腺の血流は, 温度の上昇とともに緩やかに上昇した。つぎに, 各種抗癌剤を投与した後, 温熱療法を施行し前立腺の抗癌剂組織内濃度を測定した。温熱療法施行群で組織内抗癌剂濃度は高值を 示す傾向が得られた。 また，温熱療法後の前立腺では組織学的に間質の浮腫，らっ血が観察された。

14例の前立腺癌患者に etoposide, peplomycinによる化学療法を併用した局所温熱療法を施行した。 泌尿器科がんの治療効果判定基準（案）では， CR 1 例，PR 3 例，NC 10例であり PD 症例はなかった。 副作用は，骨䯣抑制，食欲不振，下㢉，下腹部の熱傷がみられたが，重篤なものはなく治療の継続は可 能であった。

化学療法併用局所温熱療法は前立腺癌に対し安全に施行でき，かつ有用であると考兄られた。 キーワード：局所温熱療法, 前立腺, 前立腺癌

緒言

電気式加温法の進歩に伴い深部腫瘍に対する加温が
可能となった，泌尿器科領域の腫瘍に対しても温熱療 法が施されるようになり, 臨床効果も報告されてき 
た ${ }^{1) 6)}$. 前立腺に対する温熱療法の研究も報告されて はいるが7)8), $13.56 \mathrm{MHz}, \mathrm{RF}$ 波を使用した基礎掞よび 臨床的研究は少ない。

本研究では，前立腺における温度分布，血流ならび に各種抗癌剂を併用した場合の組織内濃度に関して実 験的検討を行った。 また, 臨床効果に関しても検討を 行った。

\section{対象及び方法}

雄性雑種犬を購入し，正常イヌとして使用した。使 用したイヌ 40 頭の平均体重は $10.5 \mathrm{~kg}$ であった。経静脈 的にペントバルビタール $30 \mathrm{mg} / \mathrm{kg}$ を投与し麻酔した 後, イヌの直腸に円筒型の内腔式アプリヶーターを留 置し, 下腹部に矩型のアプリケーターを装着しオリン パス社製 Endoradiotherm $100 \mathrm{~A}{ }^{\circledR} よ り 13.56 \mathrm{MHz}$ の $\mathrm{RF}$ 波を発生し加温を行った（図 1).

温度は，同じくオリンパス社製熱電対を用いて測定 した。すなわち，開腹してェラスター針を使用して前 立腺を直接穿刺するかまたは, 経会陰的に穿刺, ある いはバルーンカテーテルに熱電対を装着して経時的に 行った。な怙，このとき $\mathrm{RF}$ 波の出力は $100 \mathrm{~W}$ とした. また，小さな前立腺では測定部位が曖昧となるため前 立腺径が約 $3 \mathrm{~cm}$ の比較的大きなものを温度測定に使 用した。

血流に関しては, バイオメディカルサイェンス社製 電解式組織血流計（Model RBF-2）を使用して水素ガ スクリアランス法9)で 2 電極方式を用い前立腺及び周 辺筋組織の血流を測定した. 加温施行前, 臟器の温度 が $42^{\circ} \mathrm{C}, 45^{\circ} \mathrm{C}$ の時点でそれぞれ 4 回の測定を行いその

図 1 本実験の略図. 2 種類のアプリヶーターを犬に 装着している。

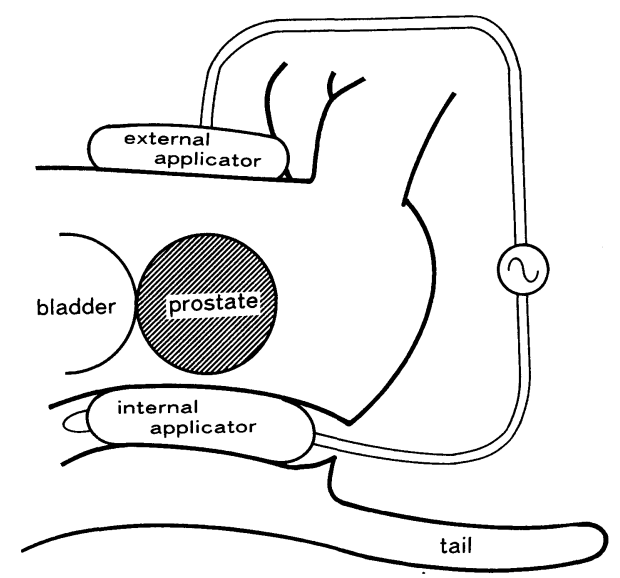

平均を測定結果とした。

抗癌剂は, etoposide, peplomycin (PEP), cisdiammine-dichloro-platinum (II) (CDDP)（いずれ も日本化薬社製・東京）を使用した。 また，CDDP 含 有温熱感受性リポソームに関しても検討を行った。こ れらの抗癌剤をそれぞれ, etoposide $5 \mathrm{mg} / \mathrm{kg}$, PEP 3 $\mathrm{mg} / \mathrm{kg}, \mathrm{CDDP} 5 \mathrm{mg} / \mathrm{kg}, \mathrm{CDDP}$ 含有感受性リポソー ムは CDDP 量として $1 \mathrm{mg} / \mathrm{kg}$ で経静脈的に麻酔下の イヌへ投与を行った. 1 時間の加温の後に前立腺, 腎, 肝, 小腸, 筋, 肺の諸臓器を速やかに摘出し組織内濃 度の測定に供した。組織内濃度の測定は, etoposide で は高速液体クロマトグラフィー法, PEPではペーパー ディスク寒天板拡散法, CDDP では原子吸光法で行っ た。 また，対照として温熱療法を施行せず抗癌剤の投 与のみを行い, 投与 1 時間後に諸臓器を摘出した群を 設けてこれを非加温群とし，加温群との間で $\mathrm{T}$ 検定に よる統計学的検討を行った. 同様に抗癌剤投与後の同 一個体での温熱療法の影響を観察するため, 局所加温 を受けた筋組織と加温を受けていない筇組織において 抗癌剤濃度を測定し同じく統計学的に検討を行った。

以上の検討と同時に，摘出した前立腺，および直腸 粘膜に関して光顕による組織学的検討も行った.

\section{結 果}

熱電対を使用した温度測定の結果. 図 2 に示す。直 腸に留置したアプリケーターの側で温度がやや高く, 膀胼側で比較的低い傾向がみられた。しかし, $100 \mathrm{~W} の$ 出力で 15 分の加温の後には, 前立腺のほぼ全域で $42^{\circ} \mathrm{C}$ 以上に加温することが可能であった。

図 $2100 \mathrm{~W} ， 15$ 分間加温した後に測定した前立腺各 部の温度.

尿道温度
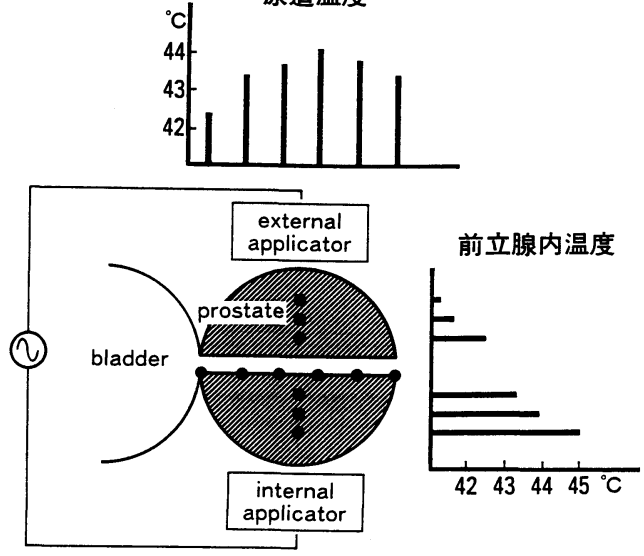
図 3 前立腺及び周辺筋組織の血流の変化.

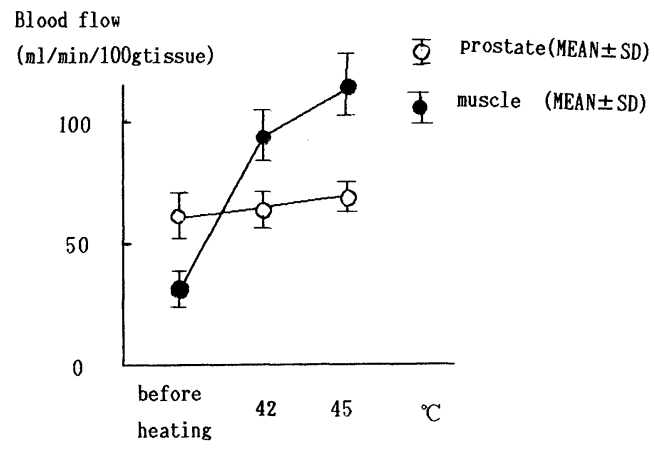

図 4 etoposide の組織内濃度. 温熱療法施行群と末 施行群の比較.

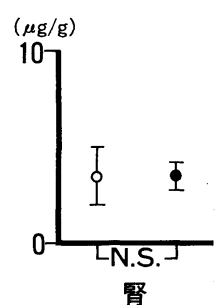

筋

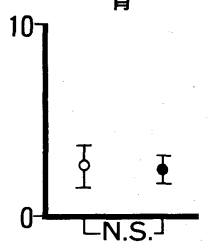

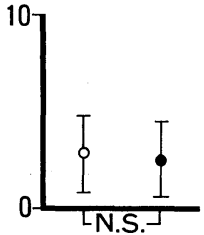

肝

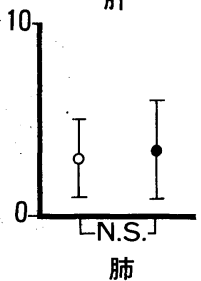

肺

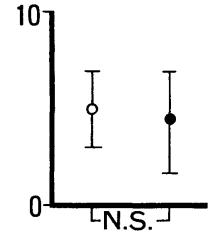

小腸

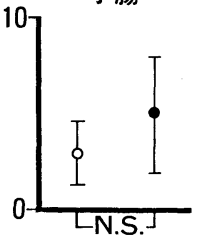

前立腺 $n:$ ずれも 4 ఏ非加温群 ゆ加温群 (MEAN \pm SD)

前立腺および周辺筋組織に対し血流測定を行った結 果, 前立腺の血流は加温前 $62.2 \mathrm{ml} / \mathrm{min} / 100 \mathrm{~g} \cdot$ tissue と, 筋組織の $39.0 \mathrm{ml} / \mathrm{min} / 100 \mathrm{~g} ・$ tissue に対して高値を 示した。しかし， $42^{\circ} \mathrm{C}, 45^{\circ} \mathrm{C}$ の温度下で前立腺の血液 が，それぞれ $70.1 \mathrm{ml} / \mathrm{min} / 100 \mathrm{~g} \cdot$ tissue, $75.0 \mathrm{ml} / \mathrm{min} /$ $100 \mathrm{~g} \cdot$ tissue と緩やかに上昇したのに対し筋組織の血 流は90.3ml $/ \mathrm{min} / 100 \mathrm{~g}$ •tissue, $106.9 \mathrm{ml} / \mathrm{min} / 100 \mathrm{~g} \bullet$ tissue と急激に増加していた（図 3 ）.

Etoposide, PEP, CDDP を経静脈的に投与した後の 諸藏器の組織内濃度を示す(図 4 , 図 5 , 図 6 )。 3 剂 とも腎, 肝, 小腸, 筋, 肺の各臓器で統計学的有意差 はみられなかった。前立腺に関しては，CDDP 投与に おいて, 加温群の平均 $9.23 \mu \mathrm{g} / \mathrm{g}$ に対して, 非加温群で は4.77 $\mu \mathrm{g} / \mathrm{g}$ と加温群の組織内濃度が有意に高值を示
図 5 CDDP (Pt.) の組織内濃度. 温熱療法施行群と 末施行群の比較.
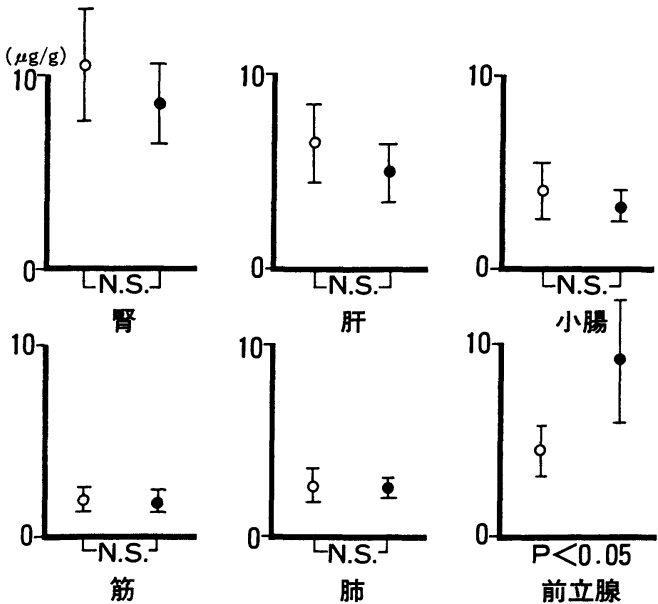

前立腺

ゆ加温群 (MEAN \pm SD)

図 6 PEP の組織内濃度. 温熱療法施行群と未施行群 の比較.

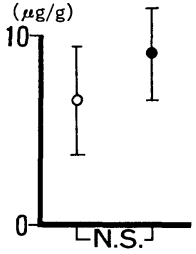

腎

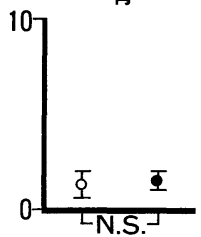

筋
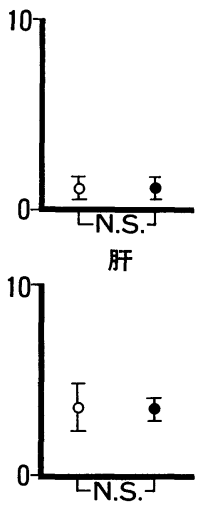

肺

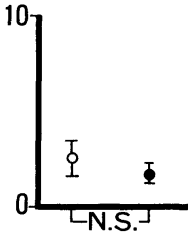

小腸

$$
n: \text { ずれも4 §非加温群 ゆ加温群 (MEAN } \pm \text { SD) }
$$

した（図 5 )。Etoposide，PEP 投与群では有意差は得 られなかった。しかし, etoposide 投与に打ける加温群 の前立腺組織内濃度は平均 $5.23 \mu \mathrm{g} / \mathrm{g}$ であり, 非加温 群の $2.82 \mu \mathrm{g} / \mathrm{g}$ と比較し, 加温群で高値を示す傾向が 観察された. PEP に関しても同様に加温群の平均 3.67 $\mu \mathrm{g} / \mathrm{g}$ に対して非加温群の平均は $2.79 \mu \mathrm{g} / \mathrm{g}$ であった。 CDDP 含有熱感受性リポソームを CDDP 量として1 $\mathrm{mg} / \mathrm{kg}$ 投与した結果, 小腸, 筋では測定感度以下であ り，腎，肺では加温群でやや高値を示す傾向がえられ たが有意差はなかった。前立腺では非加温群で測定し 
図 7 同一個体に抢ける局所加温の影響. 加温を受けた筋組織と非加温筋組織の抗癌 剤濃度の検討

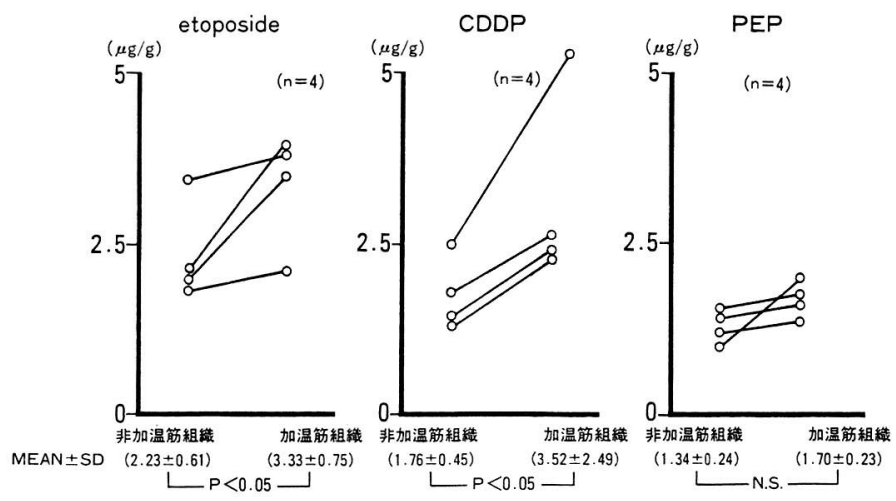

表 1 CDDP 含有熱感受性リポソーム投与後の前立腺 内 $\mathrm{CDDP}$ (Pt.) 濃度

\begin{tabular}{c|c|c|c}
\hline No. & 非加温群 & No. & 加 温 群 \\
\hline 1 & $<0.08 \mu \mathrm{g} / \mathrm{g}$ & 5 & $<0.08 \mu \mathrm{g} / \mathrm{g}$ \\
2 & $<0.08 \mu \mathrm{g} / \mathrm{g}$ & 6 & $0.18 \mu \mathrm{g} / \mathrm{g}$ \\
3 & $<0.08 \mu \mathrm{g} / \mathrm{g}$ & 7 & $0.08 \mu \mathrm{g} / \mathrm{g}$ \\
4 & $<0.08 \mu \mathrm{g} / \mathrm{g}$ & 8 & $0.92 \mu \mathrm{g} / \mathrm{g}$ \\
\hline
\end{tabular}

た 4 前立腺とも測定感度以下であったのに対し加温群 では 4 前立腺中 3 前立腺で測定が可能であった（表 $1)$.

同一個体における温熱療法の影響を検討するため加 温を受けた筋組織と，加温を受けていない筋組織の抗 癌剂濃度を測定した. Etoposide, CDDP に抢いて, 非 加温筋組織に対し，加温筋組織では有意に組織内濃度 は高値を示した。PEPでは有意差は得られなかった が，加温筋組織で高值を示す傾向がみられた（図 7 ).

温熱療法のみを施行したイヌより前立腺を摘出し， 光顕組織像を検討した。間質の浮腫(図 8a)およびうっ 血（図 8b）が前立腺全体にみられた。しかし，個々の 細胞はその形態が保たれていた。直腸粘膜には肉盟的 には著変なく, 組織学的には前立腺と同様, 間質の浮 腫およびうっ血がみられた。

\section{臨床的研究}

14名の前立腺癌症例に対して etoposide, PEPによ る化学療法を併用した局所温熱療法を施行した，症例 の内訳は，再燃例 7 例，未治療例 7 例であり, stage は B2が 1 例，Cが 9 例，D が 4 例であった．年齢は， 52 歳から87歳までであり，平均71.4歳であった。組織型 は高分化腺癌が 2 例，中分化腺癌 5 例，低分化腺癌 6
図 $8 \mathrm{a}$ 温熱疫法施行後のイヌ前立腺光顕組織像. 間質 の浮腫がみられる $(\mathrm{HE} . \times 150)$.

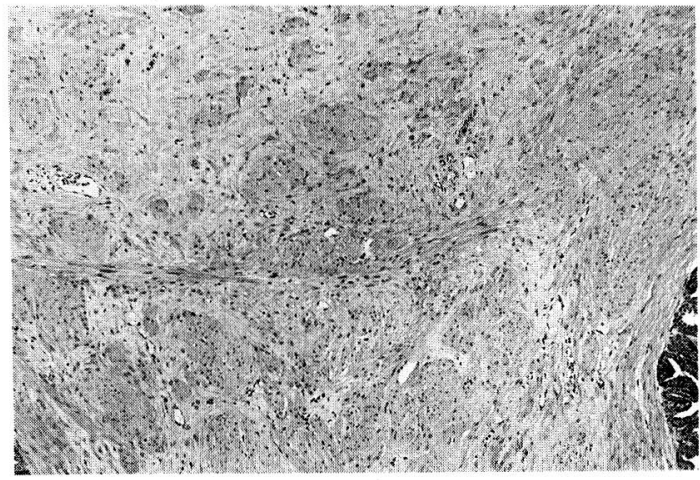

困 $8 \mathrm{~b}$ 温熱療法施行後のイヌ前立腺光顕組織像. うっ 血がみられる (HE. ×200).

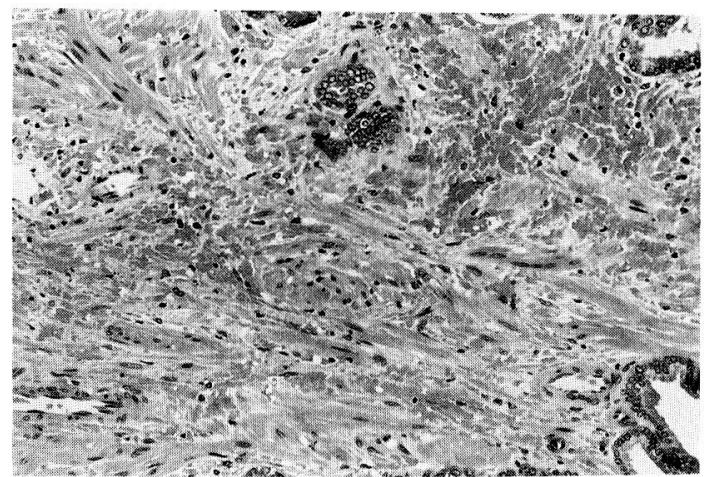

例，扁平上皮癌 1 例であった（表 2 ）.

これらの症例に対してイヌを用いた基礎的加温実験 に基づき，アプリケーターを装着し治療を行った。な 
表 2 前立腺癌症例治療の概略

\begin{tabular}{|c|c|c|c|c|c|c|c|c|c|c|c|}
\hline No & 症例 & 年齢 & stage & 病理 & $\begin{array}{c}\text { 温熱療法 } \\
\text { 回数 }\end{array}$ & $\begin{array}{l}\text { Etoposide } \\
\text { (mg) }\end{array}$ & $\begin{array}{l}\text { PEP } \\
(\mathrm{mg})\end{array}$ & $\begin{array}{l}\text { 組織学的 } \\
\text { 治療効果 }\end{array}$ & $\begin{array}{l}\text { 前立腺 } \\
\text { 縮小率 }\end{array}$ & $\begin{array}{l}\text { 効果 } \\
\text { 判定 }\end{array}$ & 転 \\
\hline 1 & S. T. & 83 & $\mathrm{C}$ & 高 & 20 & 500 & 15 & $\mathrm{G} 2$ & $54 \%$ & PR & 4 年 1 月生 \\
\hline 2 & M. Y. & 87 & $\mathrm{C}$ & 低 & 10 & 600 & 0 & $\mathrm{G} 2$ & 12 & $\mathrm{NC}$ & 2 年 5 月死(肺炎) \\
\hline 3 & I. I. & 71 & $\mathrm{D}_{1}$ & 中 & 10 & 950 & 45 & G2 & 45 & $\mathrm{NC}$ & 3 年 1 月生 \\
\hline 4 & T. S. & 64 & $\mathrm{C}$ & 低 & 10 & 700 & 0 & G1 & 73 & PR & 6 月死(肺炎) \\
\hline 5 & Y. I. & 55 & $\mathrm{D}_{2}$ & 中 & 10 & 550 & 50 & G1 & 23 & $\mathrm{NC}$ & 3 年生 \\
\hline 6 & H. K. & 77 & $\mathrm{~B}_{2}$ & 中 & 10 & 900 & 15 & G3 & 35 & $\mathrm{CR}$ & 2 年 6 月生 \\
\hline 7 & S. S. & 65 & $\mathrm{C}$ & 高 & 10 & 900 & 10 & G1 & 33 & $\mathrm{NC}$ & 2 年 5 月生 \\
\hline 8 & M. D. & 68 & $\mathrm{C}$ & 中 & 20 & 1000 & 85 & G1 & 0 & $\mathrm{NC}$ & 9 月癌死 \\
\hline 9 & J.S. & 76 & $\mathrm{C}$ & 扁 & 20 & 700 & 60 & G2 & 30 & $\mathrm{NC}$ & 4 年 3 月生(前立腺全摘除術) \\
\hline 10 & Y.S. & 52 & $\mathrm{C}$ & 中 & 10 & 1000 & 50 & G1 & 30 & $\mathrm{NC}$ & 3 年 2 月癌死 \\
\hline 11 & H. H. & 70 & $\mathrm{D}_{2}$ & 低 & 10 & 1000 & 50 & 生検不可 & 38 & $\mathrm{NC}$ & 1 年 6 月癌死 \\
\hline 12 & T. U. & 76 & $\mathrm{C}$ & 低 & 11 & 900 & 0 & $\mathrm{G} 1$ & 31 & NC & 1 年 8 月死 (脳梗塞) \\
\hline 13 & K. S. & 80 & $\mathrm{C}$ & 低 & 10 & 700 & 50 & G2 & 34 & $\mathrm{NC}$ & 3 月死(心筋梗塞) \\
\hline 14 & F. I. & 75 & $\mathrm{D}_{2}$ & 中 & 11 & 1000 & 0 & G1 & 62 & PR & 1 年 4 月生 \\
\hline
\end{tabular}

症例 $1-7$ は, 未治療症例。 8-14は, 再然症例.

病理：低…低分化腺癌組織学的治療効果, 効果判定は泌尿器科がんの

中...中分化腺癌

高...高分化腺癌

扁…扁平上皮癌

治療効果判定基準（案）による

1991年 8 月現在

お, 各温熱療法の直前に etoposide 100mg, PEP $5 \mathrm{mg}$ を経静脈的に投与している。温熱療法は，加温を 1 回 30 分とし，各症例につき週 2 回，計10回を目標とした。 腫瘍内温度は， $42 \sim 44^{\circ} \mathrm{C}$ とした。腫瘍内温度測定は, 経会陰的に腫瘍を直接穿刺して熱電対で測定した。

治療の概略を表 2 に示す．未治療例では治療後, 12 73\%の腫瘍の縮小が得られ，平均縮小率は $40.0 \%$ であった，未治療例は本治療終了後，全例が去勢術を 施行され，diethylstilbesterol (DES) の投与を受けて いる. 2 年 9 月の平均観察期間中，肺炎で死亡した 2 例を除き，全症例再然の徵候なく良好に経過している。 再然例では腫汪縮小効果は，6 例にみられ，縮小率は 平均 $33.0 \%$ であった。筋梗塞, 脳梗塞でそれぞれ 1 例が死亡， 3 例は癌性悪液質により死亡している。現 在, 生存症例は 2 例であり, このうち 1 例は前立腺全 摘除術を施行した。

腫瘍マーカーである前立腺酸性フォスファターゼが 治療前高值を示した症例は，未治療例で 5 例，再燃例 で 4 例存在した。治療後は，全例で低下を示した。し かし，正常值を示した症例は，未治療例で 1 例，再治 療例で 3 例のみであった。

治療の直後に13例に対し前立腺生検を施行した。間 質の浮腫，線維化がほとんどの症例で観察された。ま た，核凝集，壊死などは半数の症例で認められた。泌
表 3 本療法による副作用

\begin{tabular}{l|c}
\hline & cases \\
\hline Bone marrow supression & $12(85.7 \%)$ \\
Decrease of $\mathrm{PaO}_{2}$ & $2(14.3 \%)$ \\
Appetite loss & $8(57.1 \%)$ \\
Hair loss & $6(42.9 \%)$ \\
Diarrhea & $4(28.6 \%)$ \\
Urethral pain & $1(7.2 \%)$ \\
Skin burns & $1(7.2 \%)$ \\
\hline
\end{tabular}

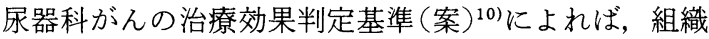
学的治療効果は, G3が 1 例, G2, G1は，それぞれ 5 例, 7 例であった（表 2 ).

以上より同じく泌尿器科がんの治療効果判定基準 (案) ${ }^{10)}$ で CR 1 例, PR 3 例, NC 10例と判定された(表 2).

本療法により認められた副作用を表 3 に示す。骨髄 抑制, $\mathrm{PaO}_{2}$ の減少，食欲不振，脱毛は，抗癌剤による と考兄られた，尿道痛，下腹部の第 1 度熱傷がそれぞ れ 1 例ずつにみられたが，これらは温熱療法によるも のと考觉られた。

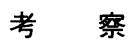

$100 \mathrm{MHz}$ 以下の $\mathrm{RF}$ 波は，生体では低周波として扱 われ，ほぼ直進し，生体での透過性が高いと考兄られ 
ている ${ }^{11)}$.そのため, 従来より深部腫瘍の加温に利用さ れてきた ${ }^{12)}$.しかし，電極を体外に置いた場合，骨，腸 管内ガスが存在するため縦隔, 骨盤内臓器の加温は困 難であると考えられてきた ${ }^{13) \sim 15)}$. 内腔式アプリケー ターを利用した本法では腸管内ガスの影響を比較的受 けずにすみ，食道，子宮などを代表とする綎隔，骨盤 内諸藏器に対して応用が研究されてきた ${ }^{16) 17)}$ 。前立腺 においても他の骨盤内臟器と同様, 内腔式アプリヶー ターを使用した場合の有用性が期待された。 また， RF 波を用いた本法では電極サイズ，電極間距離などの違 いを利用して加温する位置，領域などを調整すること が可能であり ${ }^{12)}$, しかも, 人体も共振しやすいとされて いる30 300MHz の周波数 ${ }^{18)}$ より低い周波数を使用 しており，内腔式アプリケーターを使用しているため 比較的低出力で加温が可能であるなど1)電磁界防護に 対する安全面に関しても好ましい方法であると考兄ら れた。

本研究では，まず，温度の上昇が期待できるかを判 断するため熱電対を用いて温度測定を行った。加温開 始後, イヌ前立腺内の温度は上昇し, $100 \mathrm{~W}$ の出力の場 合約15分後に前立腺のほ葟全域で温熱療法の至適温度 とされている $42^{\circ} \mathrm{C}$ 以上に加温することが可能であった (図 2 ). 臨床に扔いても $42^{\circ} \mathrm{C}$ 以上に加温が可能である ことが確認されている4).

血流に関しては, 加温施行前の状態では前立腺の血 流は周辺組織に比べて高値を示していたが, $42^{\circ} \mathrm{C}, 45^{\circ} \mathrm{C}$ では周辺筋組織の血流が前立腺のそれを上回ってい た．加温環境下では前立腺の血流は周辺筋組織に対し て比較的血流が乏しい状態にあるのではないかと考兄 られた。腫瘍血管内皮が加温の影響を受け浮腫, 壊死 を起こし血流を低下させるとする報告がある19220)，正 常イ又前立腺では加温後, 組織学的に前立腺間質の浮 腫とうっ血が観察されている. 前立腺内の血管にも腫 瘍血管に類似した変化が生じ，このために血流が周辺 筋組細に比較して低い值を示したのではないかと推測 された，前立腺は血流が豊富であるとする報告があ $り^{21)}$ ，そのため熱拡散が起こり充分な加温ができない のではないかと予測されていたが，以上の実験結果よ ク内腔式アプリケーターを用いた本法は, 前立腺の加 温に関しては充分，評価の対象になりらると考兄られ た.

抗癌剂組織内濃度の検討では etoposide, PEP にお いて温熱療法により前立腺組織内濃度が上昇する傾向 がみられ，CDDPに打いてはその傾向は顕著であっ
た。同一個体内で測定した筋組織内濃度でも加温の影 響を受けた筫組織は他に比べ抗癌剤濃度が高値を示し ていた。 以上ょり温熱療法が抗癌剤の集積を促進して いる可能性が考兄られた。温熱療法に抗癌剤を併用し た場合，温熱による抗癌剤の増感作用が期待されると する報告がある22223)．その機序の一つとして細胞膜へ の薬剂透過性の増大が挙げられている ${ }^{22}$. そのため, 今 回経験したように標的藏器に抢ける薬剤の組織内濃度 の上昇が生じるのではないかと考兄られた。同時に， 前述したごとく局所加温下では前立腺の組織血流は周 辺筋組織の血流に対して比較的乏しい状態にあると考 えられ，その状態のものとでは薬剤の組織での停滞が 期待される。このために組織内濃度が上昇する可能性 も考えられた。

また，局所温熱療法は熱を腫瘍に集中させることが 可能であるため，この熱を利用して，薬剤を標的とし ての腫瘍に集積させる試みが検討されている，すなわ ち, 加温された腫瘍に抗癌剂含有熱感受性リポソーム を投与するとリポソーム膜はゲル相から液晶層へ相転 移を起こし，この時，封入された抗癌剤はリポソーム 外へ抬散するといらものである ${ }^{24)}$. 本研究では CDDP 含有熱感受性リポソームを用いた。その結果, 非加温 群では測定感度以下の濃度であったのに対して加温群 では 4 前立腺中 3 前立腺で測定可能な濃度が得られて いる，以上より，温熱療法による抗癌剤の標的臟器へ の集積の可能性が本研究により初めて前立腺において も示唆されたとい兄よう。

Huggins $^{25}$ 以来, 前立腺癌はホルモン依存癌として 治療面に打いて発展してきたが，ホルモン抵抗癌と なった場合，急速に発育し患者を死にいたらしめる。 各種抗癌剂を用いた治療が試行されているが満足すべ き効果が得られているとは言い切れず26)，その治療に は苦慮するところである。そのため, 温熱療法に着目 し，その治療効果を検討すべき本研究を行った。しか し, 実際の臨床においては, 温熱療法単独による治療 成績はは注ど良好なものとはいえない報告が多いた め ${ }^{27)}$, 本研究でも抗癌剂との併用を行った。すなわち, 従来より前立腺癌に対し単剂でもある程度の効果が報 告されている $\mathrm{PEP}^{28)}$ と, 比較的新しい薬剤であるが単 剂で $15.4 \%$ の有効率があり ${ }^{29)}$ ，細胞周期上の作用点の 相違から温熱療法との併用が期待できる etoposideを 使用した ${ }^{30)}$. この 2 剂による化学療法を併用した局所 温熱療法の結果, 14例中13例で画像診断上, 前立腺腫 瘍の縮小が得られ, 組織学的治療効果でも G3, G2を 13 
例中 6 例に認めた. 泌尿器科がんの治療効果判定基準 (案) ${ }^{10)}$ で CR 1 例, PR 3 例と判定され PD を示す症例 はなかった。また, 重篤な副作用はなく, 高龄, 循環 器系に合併症を有するなど危険因子の多い症例におい ても本療法は安全に施行しらると考光られた。

近年では stage $C, D_{1}$ 症例に対しても前立腺全摘除 術が行われ，良好な成績が報告されている31132).すなわ ち, 進行癌においても原発巣局所の治療が重要である 可能性が示唆されている.自験例において本療法の後, 前立腺全摘除術が 1 例に施行されている. 当教室で経 験した再燃前立腺癌症例中, 全摘除術が可能となった のは本症例のみである。この症例では down staging が果たされており, 術後の再発はなく今回対象とした 全症例中最長の生存期間を得ている.他の症例でも G3 を得られた 1 例を始めとしてなんらかの組織学的効果 が得られた。すなわち, 本研究により局所温熱療法の 術前 surgical neoadjuvant としての有用性が示唆さ れたとい党よう。

以上述べたごとく, 前立腺癌に対する本療法は, そ の加温能力, 治療効果ともに十分評価に耐兄られるも のであり, 今後のさらなる発展, 普及が望まれる.

\section{結語}

$13.56 \mathrm{MHz}, \mathrm{RF}$ 波を用いた局所温熱療法に関する 検討を行った. 正常イヌ前立腺では満足すべき温度分 布が得られ, 各種抗癌剂の組織内濃度が上昇する傾向 が得られた。

14例の前立腺癌症例に対して化学療法併用局所温熱 療法を施行した結果, 平均 $35.7 \%$ の腫瘍縮小率が得ら れ，6症例で $\mathrm{G} 2$ 以上の組織学的治療効果が得られた。

本研究により, 前立腺癌に対する局所温熱療法の有 用性が明らかとなり，また， surgical neoadjuvan とし ての有用性が示唆された。

稿を終兄るにあたり, 御指導頂いた東京大学阿曾佳郎教 授, 東京大学分院田島 惊助教授, 浜松医科大河邊香月教 授，鈴木和雄助教授に深謝致します。

\section{文献}

1）平井正孝, 中野 優, 牛山知已, 増田宏昭, 太田信 隆, 田島 嵉, 河邊香月, 阿曾佳郎：前立腺癌に対 する温熱療法の試み。日泌尿会誌, 79, 1761-1764, 1988.

2) Hirai, M., Nakano, M., Masuda, H., Ushiyama, T., Ohta, N., Tajima, A., Kawabe, K. and Aso, Y.: Combination therapy of prostatic cancer by hyperthermia and chemotherapy. Proceedings of the 5th International Symposium on
Hyperthermic Oncology, Vol. 1, 546-547, 1989.

3) Hirai, M. and Masuda, H.: Thermochemotherapy for prostatic cancer. Proceeding of the 6th Annual Meeting, the Society of Hyperthermic Oncology, 132-133, 1990.

4）平井正孝：前立腺癌に対する温熱療法. 泌尿紀要, 37, 833-836, 1991.

5）窪田吉信：膀腅癌の温熱療法. 泌尿器外科, 1, 815-824, 1988.

6）中嶋和喜, 久住治男, 山本 肇, 内藤克輔, 三崎俊 光, 小橋一功, 横山 修, 斉藤泰雄: 手術不能の進 行泌尿性器悪性腫瑒に対する $8 \mathrm{MHz}-\mathrm{RF}$ 加温療法 の研究(第 2 報). 日泌尿会誌, 77, 304-309, 1986.

7) Mendecki, J., Friendenthal, E., Botstein, C., Paglione, R. and Sterzer, F.: Microwave applicators for localized hyperthermia treatment of cancer of the prostate. Int. J. Radiation Oncol. Biol. Phys., 6, 1583-1588, 1980.

8) Yerushalimi, A., Shpirer, Z., Hod, I., Gottesfeld, F. and Bass, D.: Normal tissue response to localized deep microwave hyperthermia in the Rabbit's prostate: A preclinical study. Int. J. Radiation Oncol. Biol. Phys., 9, 77-82, 1982.

9) Aukland, K., Bower, B.F. and Berliner, R.W.: Measurement of local blood flow with hydrogen gas. Cric. Res., 14, 164-187, 1964.

10) 日本泌尿器科学会・ 日本病理学会・日本癌治療学会 編：泌尿器科がんの治療効果判定基準 (案). 3 . 前立腺癌の治療効果判定基準 (案). p. 33-44, 東 京, 1991.

11）斉藤正男：物理的エネルギーと加温の基礎. 癌の 臨床別集 14 , 癌・温熱療法, 第 1 版, p. 18-26, 篠原出版, 東京, 1987 .

12）塩崎 忠：Hyperthermiaにおける Radio Frequency 加温装置. 癌の臨床別集 14 , 癌・温熱療法, 第 1 版, p. 51-56, 篠原出版, 東京, 1987.

13）菅原 努：温熱療法の史的展望. 癌の臨床別集 14 , 癌・温熱療法, 第 1 版, p. 3-9, 篠原出版, 東京, 1987.

14）窪田吉信：ハイパーサーミアの臨床. 局所加温 一深部腫瘍, 膀脱・前立腺。最新医学, 40 , 2588-2593, 1985.

15）久住治男, 中嶋和喜：膀胱・前立腺癌に対する温熱 療法. 図説臨床「癌了シリーズ 18 , 癌と温熱療法, p. 121-125, メジカルビュ一社, 東京, 1987.

16）杉町圭蔵, 森 正樹：食道癌に対する温熱療法. 図 説臨床[癌]シリーズ 18 , 癌と温熱療法, p. 88-94, メジカルビュー社, 東京, 1987.

17）関場 香, 河野一郎, 長谷川俊水, 早瀬良二, 藤原 恵一, 小橋勇二 : 子宮癌に対する温熱療法. 因説臨 床 [癌]シリーズ 18 , 癌と温熱療法, p. 115-120, メジカルビュー社, 東京, 1987. 
18）小林 泉: $144 \mathrm{MHz}$ Band Report. C.Q. Ham Radio, 45, 456-457, 1990.

19）田中敬正, 長谷川武夫, 沢田 敏, 赤木 清, 村田 貴史, 河 相吉, 播磨敬三：癌の血行動態に及ぼす 温熱の影響. 癌の臨床別集 14 , 癌・温熱療法, 第 1 版, p. 128-136, 篠原出版, 東京, 1987.

20) Badylak, S.F., Babbs, C.F., Skojac, T.M., Voorhees, V.D. and Richardson, R.C. : Hyperthermia-induced vascular injury in normal and neoplastic tissue. Cancer, 56, 991-1000, 1985 .

21）島崎 淳, 布施秀樹, 秋元 晋, 赤倉功一郎：前立 腺癌の治療の現況. 癌と化学療法, 15, 212-218, 1988.

22) Hahn, G.M., Braun, J. and Har-kedar, I. : Thermochemotherapy: Synergism between hyperthermia $\left(42-43^{\circ}\right)$ and adriamycin (or bleomycin) in mammalian cell inactivation. Proc. Nat. Acad. Sci. U.S.A., 72, 937-940, 1975.

23）石渡淳一, 江川直人, 佐々木常雄, 前田義治, 松田 忠義：抗癌剂併用温熱療法. 図説臨床 [癌]シリー ズ18, 癌と温熱療法, p. 67-71, メジカルビュー 社, 東京, 1987.

24）小川泰亮：温熱感受性リポソームとハイパーサー ミア治療の併用による腫瘍の標的治療. p. 165 -174 , 日本メディカルセンター, 東京, 1990 .

25) Huggins, C. and Hodges, C.V.: Studies on prostatic cancer. I. The effect of castration of estrogen and of androgen injuction on serum acid phosphatases in metastatic carcinoma of the prostate. Cancer Res., 1, 293-297, 1941.

26）鈴木和雄, 阿兽佳郎, 小野佳成, 大島伸一, 藤田民 夫, 名出頼男, 福島雅典, 太田和雄：再燃前立腺癌 に対する化学療法. 再燃前立腺癌の治療一泌尿器 癌化学療法シリーズ (II), p. 61-69, 蟹書房, 東 京, 1986 .

27）阿部光幸：現状の概観と問題点. 図説臨床 [癌]シ リーズ 18 , 癌と温熱療法, p. 6-10, メジカルビュー 社, 東京, 1987.

28）水野左敏：化学療法剂と温熱効果. 癌の臨床別集 14, 癌・温熱療法, 第 1 版, p. 145-153, 篠原出 版, 東京, 1987.

29）阿兽佳郎：泌尿器腫瘍. エトポシドーその応用, p. 89-106，協和企画通信・日本化薬，東京， 1987 .

30）加納永一, 新田和美, 古家雅代, 坪内 進, 近藤 隆：癌と温熱療法. 細胞レベル. 癌の臨床別集 14 , 癌・温熱療法, 第 1 版, p. 105-127, 篠原出版, 東京, 1987 .

31）宇佐美道之, 古武敏彦：前立腺全摘除術. 泌尿器外 科, 1，305-308，1988.

32) DeKernion, J.B., Neuwirth, H., Stein, A., Dorey, F., Stenzl, A., Hannah, J. and Blyth, B. : Prognosis of patients with stage D1 prostate carcinoma following radical prostatectomy with and without early endocrine therapy. J. Urol., 144, 700-703, 1990.

（1992年 1 月 30 日受理，特別掲載） 